\title{
Studies of the chemical composition of fruits and seeds of pawpaw (Asimina triloba (L.) Dunal)
}

\author{
Olga Grygorieva ${ }^{1 *}$, Svitlana Klymenko ${ }^{1}$, Olena Vergun ${ }^{1}$, Katarína Fatrcová-Šramková2, \\ Olga Shelepova ${ }^{3}$, Yulia Vinogradova ${ }^{3}$, Vladimíra Horčinová Sedláčková ${ }^{4}$ Ján Brindza4

\begin{abstract}
${ }^{2}$ Slovak University of Agriculture in Nitra, Faculty of Agrobiology and Food Resources,
Department of Human Nutrition, Nitra, Slovakia

${ }^{3}$ N.V. Tsitsin Main Botanical Garden of Russian Academy of Sciences, Moscow, Russia

${ }^{4}$ Slovak University of Agriculture in Nitra, Faculty of Agrobiology and Food Resources,

Institute of Biodiversity Conservation and Biosafety, Nitra, Slovakia
\end{abstract} \\ ${ }^{1}$ M.M. Gryshko National Botanical Garden of Ukraine, National Academy of Sciences, Kyiv, Ukraine
}

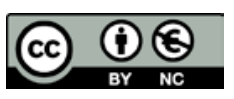

Article Details:

Received: 2021-02-20

Accepted: 2021-03-22

Available online: 2021-05-31

An international team of scientists continues to study the resource potential of non-conventional or little-utilized plants. Pawpaw (Asimina triloba (L.) Dunal) fruit (pulp and peel) and seeds were analyzed for their nutritional compositions. Seeds exhibited significantly higher levels of crude protein, lipid, and vitamin E (11.82 \%, $34.0 \%$, and $20.80 \mathrm{mg} / \mathrm{kg}$, respectively) than those of the other parts. Sucrose in pulp was $501.40 \mathrm{~g} / \mathrm{kg}$, which was the highest among the samples. There is more fructose in the peel $111.90 \mathrm{~g} / \mathrm{kg}$. Results revealed that the total amino acids in the seeds, pulp, and peel of $A$. triloba were $144.6,21.1$, and $20.9 \mathrm{~g} / \mathrm{kg}$, respectively. Among the different plant parts used in this study, the seeds contained the most abundant essential amino acid and non-essential amino acid. The glutamic acid exhibited the highest concentration among the tested amino acids. Oleic and linoleic acids in seeds were 40.13 and $38.84 \mathrm{~g} / 100 \mathrm{~g}$, respectively, which were the highest among the pulp and peel. Potassium was the most abundant essential trace mineral element in different parts. This element is present in large ammounts in the peel $(15487 \mathrm{mg} / \mathrm{kg}$ ) and pulp (12198 mg/kg) compared to the seeds (3888 mg/kg). In the seeds, P, Ca and S were higher (1937, 1368, and $1322 \mathrm{mg} / \mathrm{kg}$, respectively) than in pulp and peel $(1046,450,499$ and 831, 837, 646 mg/kg, respectively). The high content of beneficial substances makes it possible to include Asimina triloba in the list of species recommended for cultivation on a larger scale and to use its products more widely in dietary nutrition.

Keywords: pawpaw, fruits, seeds, chemical compositions

\section{Introduction}

The search for new plant species, especially neglected and underutilized plant species that are a valuable source of biologically active compounds, and creation on its basis the new generation of nutritional supplements, has recently become an urgent branch of modern biological science, and one of the most important scientific directions (Brindza et al., 2006, 2016; Klymenko et al., 2017). Guided by these new requirements, an international team of scientists has been studying for several years the content of biologically active compounds in various organs of cultivated new plants to the region (Monka et al., 2014; Ivanišová et al., 2017; Klymenko et al., 2017, 2019; Grygorieva et al., 2018; Horčinová Sedláčková et al., 2018; Grygorieva et al., 2020a, b; Vinogradova et al., 2020). This article focuses on Asimina triloba (L.) Dunal.

\footnotetext{
*Corresponding Author: Olga Grygorieva, M.M. Gryshko National Botanical Garden of Ukraine of National Academy of Sciences, Kyiv, Timiryazevska 1, 01014 Kyiv, Ukraine $\triangle$ olgrygorieva@gmail.com
} 
Asimina triloba (pawpaw, paw paw, paw-paw, common pawpaw) belongs to the family Annonaceae Juss. native to eastern North America and Canada (Layne, 1996). A. triloba fruits are rich in vitamins and minerals (Templeton et al., 2003; Pomper and Layne 2005), are a good source of potassium and several essential amino acids, and they contain significant amounts of riboflavin, niacin, calcium, phosphorus, and zinc (Galli et al., 2007), have a high polyphenolic (Harris and Brannan, 2009; Brannan et al., 2012, 2014) and antioxidant content (Kobayashi et al., 2008; Brindza et al., 2019).

A. triloba can be used as an alternative to bananas fruits in most recipes (Jones et al., 1995). Fruits of pawpaw are very fragrant and resemble a combination of aromas of banana and mango, and may be used commercially in cosmetics and skin products (Layne, 1996; Brannan et al., 2012). The extract of unripe $A$. triloba fruit has a value not only as a functional food, but has therapeutic potential for the treatment of cancer as a naturally derived substance that may be less toxic than conventional chemotherapy drugs (Nam et al., 2018b).

Biologically active compounds are not only in fruits, but in different parts of the plant: roots, bark, twigs, leaves, flowers, and seeds (Hui et al., 1989; Zhao et al., 1992, 1993, 1994; Alali et al., 1999; Goodrich et al., 2006; Cuendet et al., 2008; Farag, 2009; Pande and Akoh, 2010). The roots, twigs, flowers, and seeds of $A$. triloba contain acetogenins, which are strong inhibitors of cancer cells (Ratnayake et al., 1992; Woo et al., 1995; Ko et al., 2011; Sica et al., 2016). A. triloba leaf essential oil has strong activity against cancer cell lines (Alali et al., 1999; Farag, 2009).
A. triloba fruit, leaf, bark, and twig extract may be an effective insect feeding deterrent (Rupprecht et al., 1986; Ratnayake et al., 1992; Zhao et al., 1994; Gu et al., 1999; Sedlacek et al., 2010).

Despite the importance of $A$. triloba as a nutritional and medicinal plant in the conditions of Ukraine, this species is very little spread. Thus, the objective of the present study was to investigate and compare the nutritional compositions of pulp, peel, and seeds of A. triloba.

\section{Material and methodology}

\section{Biological material}

A. triloba (Figure 1) seeds and fruits (pulp and peel) (Figure 2) were collected in September 2020 from the trees growing in an M.M. Gryshko National Botanical Garden (Kyiv, Ukraine; 197 m a.s.l.).

\section{Chemicals}

All the chemicals used were of analytical grade and were purchased from Sigma-Aldrich (Steinheim, Germany), Merck (Darmstadt, Germany), and CentralChem (Slovakia).

\section{Phytochemical analyses}

\section{Determination of dry matter, ash, and protein content}

Total dry matter, ash, and protein content were determined according to EN method (CSN EN 12145, 1997). Total lipid content was determined according to the methods specified in ISO method (ISO 659:1998).

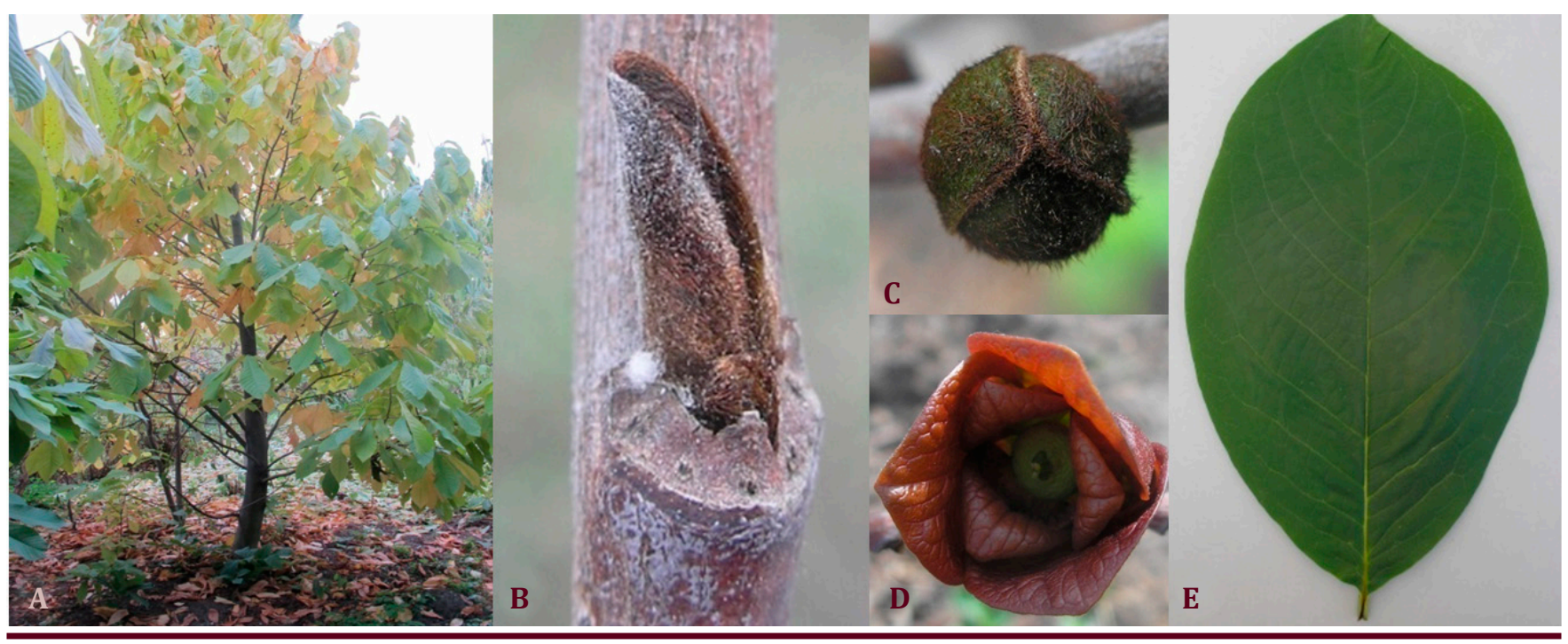

Figure 1 Tree (A), vegetative bud (B), generative bud (C), flower (D), and leaf (E) of Asimina triloba (L.) Dunal 


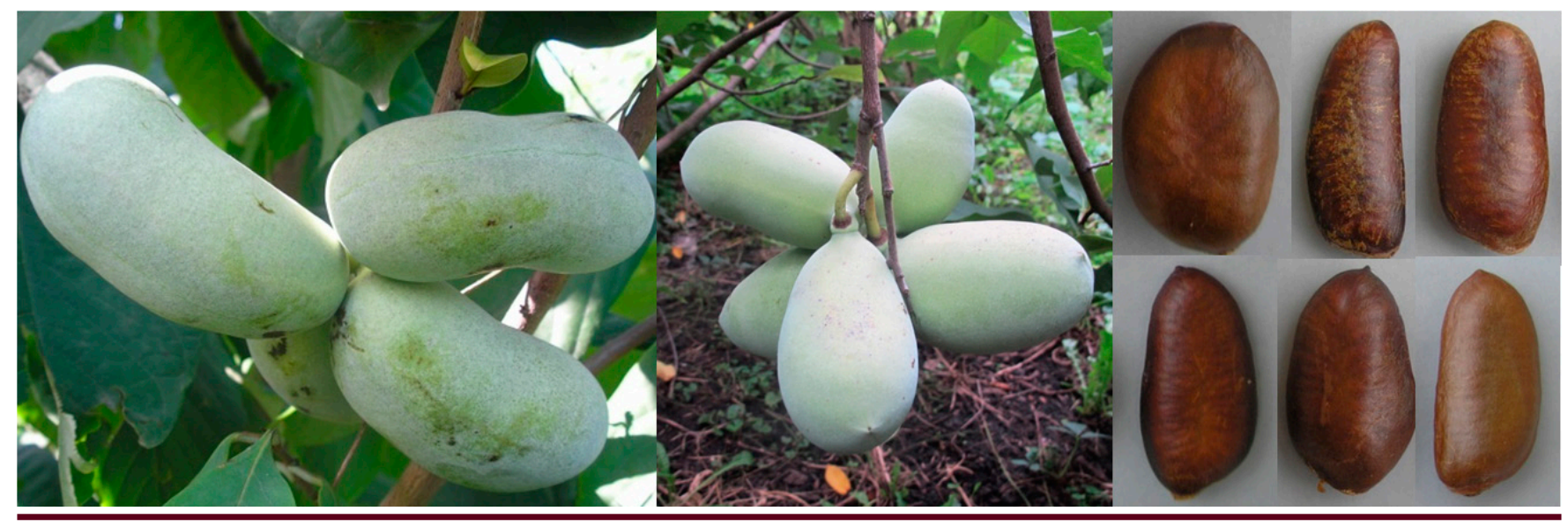

Figure 2 Fruits and seeds of Asimina triloba (L.) Dunal

\section{Determination of saccharides}

For the determination of saccharides, $1 \mathrm{~g}$ of a sample was extracted with $10 \mathrm{~mL}$ of extraction the solution (ultrapure water and ethanol mixed in a ratio of $4: 1$ ) in a $50 \mathrm{~mL}$ centrifugation tube placed on a vertical shake table (GFL, Germany). After $1 \mathrm{hr}$ of extraction, the samples were centrifuged for $4 \mathrm{~min}$ at 6000 rpm in a centrifuge (EBA 21, Hettich, Germany); the supernatant was filtered using a filter with $0.45 \mathrm{~mm}$ pore size (Labicom, Czech Republic) and filled up to $50 \mathrm{~mL}$ in a volumetric flask with ultrapure water. An Agilent Infinity 1260 liquid chromatography (Agilent Technologies, USA) equipped with ELSD detector was used for the determination of saccharides. A Prevail Carbohydrates ES column (250/4.6 mm) was used as a stationary phase and acetonitrile (VWR) mixed with water in $75: 25$ volume ratio was used as the mobile phase.

\section{Determination of carotenoid}

Total carotenoid content expressed as betacarotene was analyzed at a wavelength of $445 \mathrm{~nm}$ spectrophotometrically (VIS spectrophotometer UV Jenway Model 6405 UV/VIS). Sample (1 g) was disrupted with sea sand and extracted with acetone until complete discoloration. Petroleum-ether was added and then water with the purpose of the separation of phases. After the separation, the petroleum ethercarotenoid phase was obtained and the absorbance was measured (ČSN 560053, 1986).

\section{Determination of mineral contents}

Sample for elemental analysis was prepared using the wet ashing method in a microwave oven (Milestone 1200 , Milestone, Italy). Total of 0.25 g sample matrix was decomposed in a mixture of nitric acid $(6 \mathrm{~mL})$ (Analytika Praha Ltd, Czech Republic) and hydrochloric acid (2 mL) (Analytika Praha Ltd, Czech Republic). Then decomposition sample was filtered using a filter with $0.45 \mathrm{~mm}$ pore size and filled up to $25 \mathrm{~mL}$ in a volumetric flask with ultrapure water. Elemental analysis was performed using ICP-OES (Ultima 2, Horiba Scientific, France) according to the procedure described by Divis et al. (2015).

\section{Determination of amino acids}

Amino acids were determined by ion-exchange liquid chromatography (Model AAA-400 amino acid analyzer, Ingos, Czech Republic) using post-column derivatization with ninhydrin and a VIS detector. A glass column (inner diameter $3.7 \mathrm{~mm}$, length $350 \mathrm{~mm}$ ) was filled manually with a strong cation exchanger in the LG ANB sodium cycle (Laboratory of Spolchemie) with average particles size $12 \mu \mathrm{M}$ and $8 \%$ porosity. The column was heated within the range of 35 to $95{ }^{\circ} \mathrm{C}$. The elution of the studied amino acids took place at a column temperature set to $74{ }^{\circ} \mathrm{C}$. A double-channel VIS detector with the inner cell volume of $5 \mu \mathrm{L}$ was set to two wavelengths: 440 and $570 \mathrm{~nm}$. A solution of ninhydrin (Ingos, Czech Republic) was prepared in $75 \%$ v/v methyl cellosolve (Ingos, Czech Republic) and in $2 \% \mathrm{v} / \mathrm{v} 4 \mathrm{M}$ acetic buffer ( $\mathrm{pH}$ 5.5). Tin chloride $\left(\mathrm{SnCl}_{2}\right)$ was used as a reducing agent. The prepared solution of ninhydrin was stored in an inert atmosphere $\left(\mathrm{N}_{2}\right)$ in darkness at $4^{\circ} \mathrm{C}$. The flow rate was $0.25(\mathrm{~mL} /$ $\min$ ) and the reactor temperature was $120^{\circ} \mathrm{C}$.

\section{Statistical analysis}

Basic statistical analyses were performed using PAST 2.17. Data were analyzed with ANOVA test and differences between means compared through the Tukey-Kramer test ( $\mathrm{p}<0.05)$. The variability of all these parameters was evaluated using descriptive statistics. 


\section{Results and discussion}

In the course of the study of the nutritional properties of $A$. triloba for a recommendation to use it as a raw material for industry, it is crucial to identify the chemical composition of the different organs of the plant.

The total protein content was 11.82, 3.64, and $3.98 \%$ in seeds, pulp, and peel, respectively (Table 1); the total lipid content was 34.0, 1.12, and $3.89 \%$, respectively. According to Nam et al. (2018a) A. triloba seeds also showed significantly higher levels of crude protein and crude lipid.

Chitturi et al. (2013) evaluated the protein levels and antioxidant potential of air-dried medicinally significant domestic fruit peels and their extracts.

Monosaccharide analysis of neutral carbohydrate part showed the presence of fructose $(4.20,87.10$, and $111.90 \mathrm{~g} / \mathrm{kg}$, respectively) and sucrose (24.30, 501.40, and $227.50 \mathrm{~g} / \mathrm{kg}$, respectively) in seeds, pulp, and peel, respectively, while other saccharides, such as maltose and lactose were found only in low amounts only $(<0.5 \mathrm{~g} / \mathrm{kg})$. Nam et al. (2018a) showed that fructose, glucose, and sucrose showed the highest levels in the fruit of $A$. triloba at $1691.35 \mathrm{mg} \%, 2148.20 \mathrm{mg} \%$, and $9321.24 \mathrm{mg} \%$, respectively.

The free sugar content, as has been demonstrated by Andersen (1986), depends on the following climatic characteristics: temperature, rainfall, relative humidity, and degree of light.
Therefore, the phytochemical composition of $A$. triloba, including free sugars is expected to vary according to cultivation conditions. At the same time, the intensity of sweetness from free sugars and their composition will differ depending on the plant organs.

Carotenoids are widely distributed in nature. They are diverse in structure and in their function for human health. Carotenoids are useful for the prevention of certain types of cancer. They can prevent photosensitization in some skin diseases and increase immune response in infections. Their anti-aging effects on the human body are also known (Kurahashi et al., 2009).

A. triloba contains beta carotene in seeds, pulp, and peel $(4.80,6.60$, and $12.70 \mathrm{mg} / \mathrm{kg}$, respectively). As shown from the results, beta carotene accumulated in peel 2 times more than in pulp and approximately 3 times more than in seeds. Differents fruits investigation on $\beta$-carotene content showed that in the peel this vitamin concentrated the most. Ghosh et al. (2019) believe the presence of $\beta$-carotene in fruit peel wastes might be a contributing factor for its antioxidant activities. Citrus reticulata Blanco (Ghosh et al., 2019), Mangifera indica L. (Ranganath et al., 2018; Ghosh et al., 2019), Musa acuminata Colla (Budhalakoti, 2018), Malus domestica Borkh. (Delgado-Pelayo et al., 2014) have a high in $\beta$-carotene content and they also show potential antioxidant activity. According to Arora et al. (2008), banana peel could be a potential source of carotenoids. The content of carotenoids and $\beta$-carotene depends

Table 1 Contents of some phytochemical compounds of Asimina triloba (L.) Dunal

\begin{tabular}{|l||c|c|c|}
\hline Components & Seeds $\left(\overline{\mathbf{x}} \pm \mathbf{S}_{\mathbf{x}}\right)$ & Pulp $\left(\overline{\mathbf{x}} \pm \mathbf{S}_{\mathbf{x}}\right)$ & Peel $\left(\overline{\mathbf{x}} \pm \mathbf{S}_{\mathbf{x}}\right)$ \\
\hline \hline Total dry matter (\%) & $96.73 \pm 3.06$ & $87.07 \pm 2.68$ & $84.12 \pm 2.33$ \\
\hline Total content of protein (\%) & $11.82 \pm 0.12$ & $3.64 \pm 0.05$ & $3.98 \pm 0.18$ \\
\hline Total content of ash (\%) & $1.47 \pm 0.04$ & $4.27 \pm 0.09$ & $3.04 \pm 0.05$ \\
\hline Total content of lipids (\%) & $34.0 \pm 1.02$ & $1.12 \pm 0.06$ & $12.0 \pm 0.09$ \\
\hline Beta carotene (mg/kg) & $4.80 \pm 0.05$ & $6.60 \pm 0.09$ & $25.70 \pm 0.10$ \\
\hline Saturated fatty acids (g/100 g oil) & $8.90 \pm 0.03$ & $30.50 \pm 0.60$ & $24.90 \pm 0.11$ \\
\hline Monounsaturated fatty acids (g/100 g oil) & $32.10 \pm 0.16$ & $28.0 \pm 0.09$ & $23.70 \pm 0.09$ \\
\hline Polyunsaturated fatty acids (g/100 g oil) & $46.60 \pm 1.13$ & $18.20 \pm 0.13$ & $111.90 \pm 1.16$ \\
\hline Fructose (g/kg) & $4.20 \pm 0.04$ & $87.10 \pm 0.21$ & $<0.5$ \\
\hline Maltose (g/kg) & $<0.5$ & $<0.5$ & $227.50 \pm 9.32$ \\
\hline Sucrose (g/kg) & $24.30 \pm 0.10$ & $501.40 \pm 12.18$ & $<0.5$ \\
\hline Lactose (g/kg) & $<0.5$ & $<0.5$ & $<0.1$ \\
\hline Vitamin A (retinyl acetate) (mg/kg) & $<0.1$ & $<0.1$ & $19.10 \pm 1.09$ \\
\hline Vitamin E ( $\mathbf{k}$-tocopherol) (mg/kg) & $20.80 \pm 0.08$ & $8.80 \pm 0.11$ & \\
\hline
\end{tabular}

Note: $\overline{\mathrm{x}}$ - arithmetic mean; $\mathrm{S}_{\mathrm{x}}$ - standard error of the mean 
on many factors such as degree of maturation, type of soil, climatic conditions, etc. (Dhandapani et al., 2017). Fruits and vegetable processing industries produce huge waste in the form of peels, seeds, liquid, and molasses which are a good source of carbohydrates, proteins, fibres, vitamins, and minerals (Kaur et al., 2018).

The major quantitative tocopherol in A. triloba seeds, pulp, and peel was $\alpha$-tocopherol $(20.80,8.80$, and $19.10 \mathrm{mg} / \mathrm{kg}$ DWP, respectively). The oil contents were 34.0 (seeds), 1.12 (pulp), and $3.89 \%$ (peel) dry weight plant material. The majority of plant oils are accumulated in the seeds (Bates et al., 2013) and this parameter is controlled by genetic effects (embryonic, cytoplasmic, maternal) and interactions between the genotype and environment (Liu et al., 2014).

The composition and amount of free amino acids varied among the different parts (Figure 3). The taste, flavour, and quality of various foods are directly related to the quantity and quality of free amino acids that accumulate naturally in nutrition products (Kabelova et al., 2008; Sinesio et al., 2009). Amino acid analysis has shown that the studied $A$. triloba seeds, pulp, and peel contained 18 amino acids ( 9 essential and 9 nonessential). The contents of the total amino acid of the seeds were significantly higher than those of the pulp and peel, which is consistent with previous studies that found that most of the amino acids of the seeds of $A$. triloba was in higher levels than those in the fruit (Nam et al., 2018a). The total amino acids in the seeds, pulp, and peel of $A$. triloba were 144.6, 21.1, and $20.9 \mathrm{~g} / \mathrm{kg}$, respectively. The glutamic acid exhibited the highest concentration in seeds with the highest mean content among the tested amino acids, accounting for more than $22.68 \%$ of the entire amino acid profile. Alanine, glutamic acid, and histidine were the major amino acids detected in the peel, and glutamic acid, and aspartic acid were the main amino acids found in the pulp.

Our data coincide with those of Nam et al. (2018a) that glutamic acid was the major amino acid measured in seeds having the highest level of $1396.27 \mathrm{mg} \%$.

Fatty acids play an important role in human health. Thus, they are valuable in the prevention of cardiovascular diseases, coronary heart disease, and cancer. Their role is also important in the prevention of inflammatory, thrombotic and autoimmune diseases, hypertension, type 2 diabetes, kidney diseases, rheumatoid arthritis, and ulcerative colitis (De Caterina et al., 2000; Abedi and Sahari, 2014). Lauric, palmitic, linolenic, linoleic, oleic, stearic, and myristic fatty acids have antibacterial and antifungal properties (McGaw et al., 2002; Seidel and Taylor, 2004). In this regard, we determined the fatty acid content in various organs of $A$. triloba.

Total fatty acids varied in different parts of A. triloba (Figure 4, 5, 6). The unsaturated fatty acid content was higher than the saturated fatty acid content in all samples, and the difference between unsaturated fatty acid and saturated fatty acid was more pronounced in pawpaw seeds. In contrast, the difference between the contents in pulp and peel was negligible.

In the present study, A. triloba contained palmitic acid, oleic acid, linolenic acid, and linoleic acid. Oleic

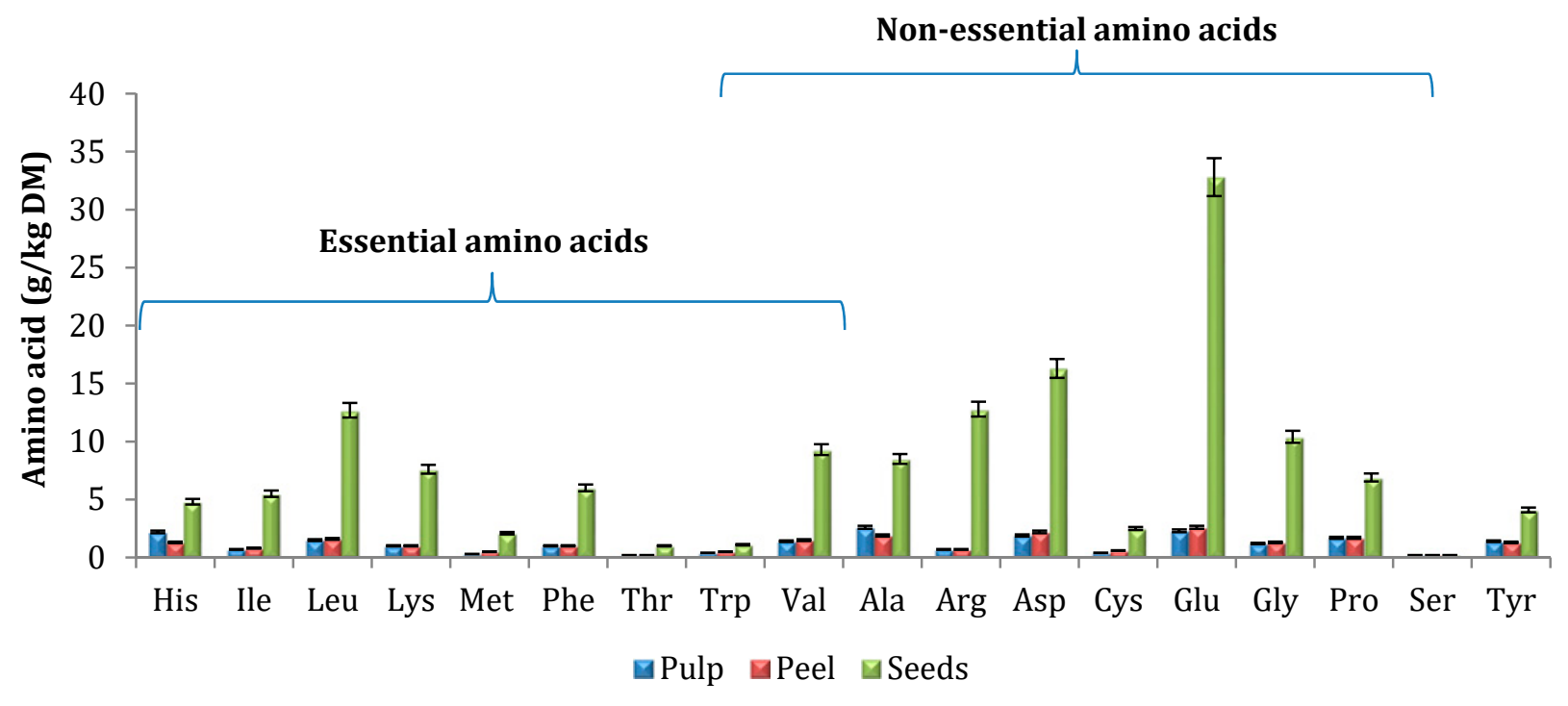

Figure 3

Amino acid composition of Asimina triloba (L.) Dunal seeds, pulp, and peel, g/kg DM (different superscripts in each column indicate the significant differences in the mean at $\mathrm{p}<0.05$ ) 


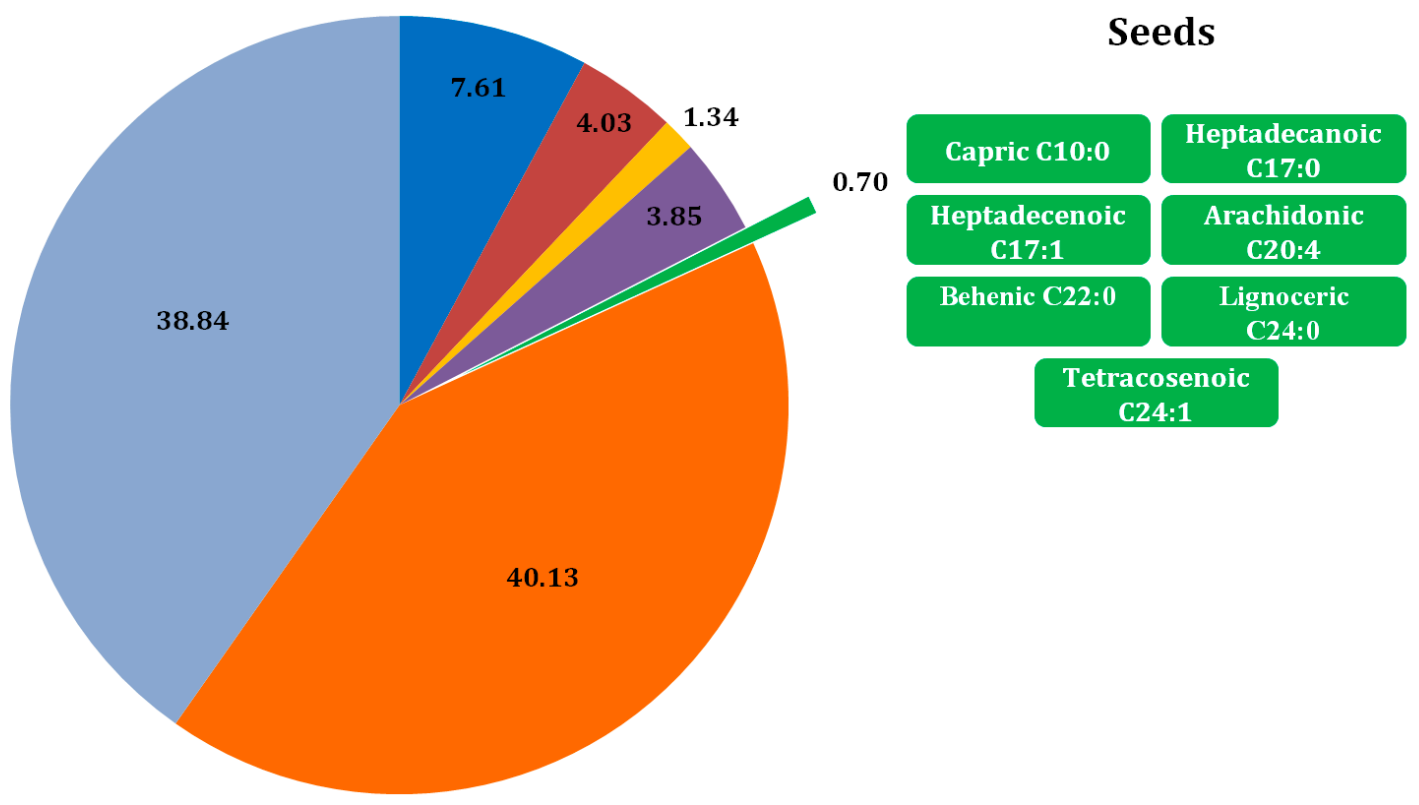

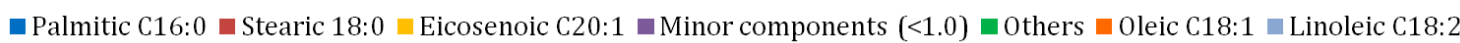

Figure 4 Fatty acid composition from seeds of Asimina triloba (L.) Dunal (g/100 g oil)

Minor components (<1.0): Caprylic C8:0 (0.32); Lauric C12:0 (0.30); Myristic C14:0 (0.26); Palmitoleic C16:1 (0.79); Linolenic C18:3 (0.80); Arachidic C20:0 (0.37); Erucic C22:1 (0.32); Docosadienoic C22:2 (0.69) are in the purple part, their total amount is $3.85 \mathrm{~g} / 100 \mathrm{~g}$ oil

acid and linoleic acid in the seeds samples were 41.59 and $40.25 \%$, respectively (Figure 4). Palmitic acid and stearic acid were the minor fatty acids in leaves, accounting for 7.89 and $4.18 \%$ of the total fatty acids, respectively. Unsaturated fatty acids were also predominant in seeds, which accounted for $86.23 \%$ of total fatty acid while saturated fatty acids accounted for $13.77 \%$.

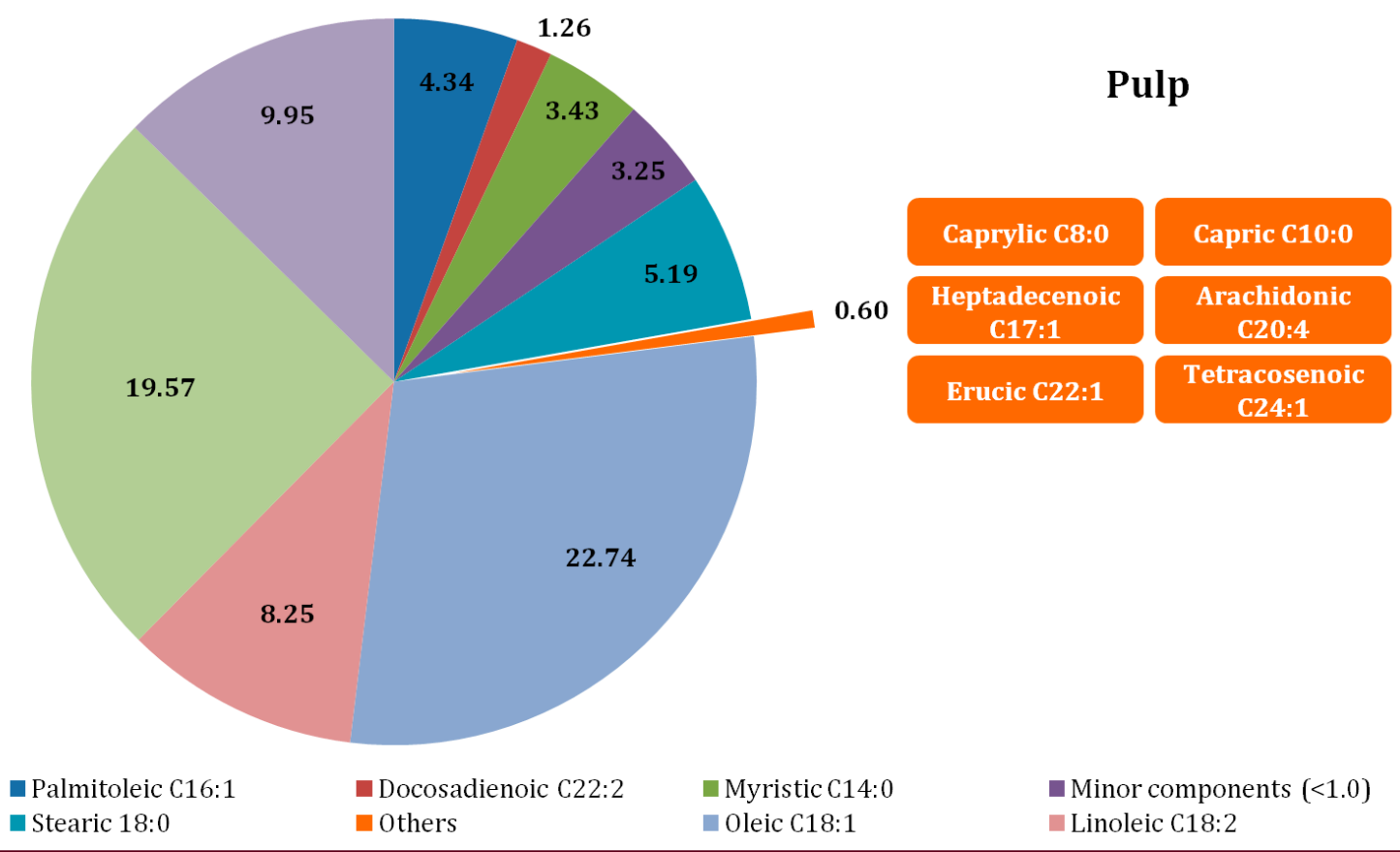

Figure 5 Fatty acid composition from pulp of Asimina triloba (L.) Dunal (g/100 g oil)

Minor components (<1.0): Lauric C12:0 (0.42); Heptadecanoic C17:0 (0.27); Arachidic C20:0 (0.30); Eicosenoic C20:1 (0.90); Behenic C22:0 (0.75); Lignoceric C24:0 (0.61) are in the right column: are in the right column, in the purple part, their total amount is $3.25 \mathrm{~g} / 100 \mathrm{~g}$ oil 


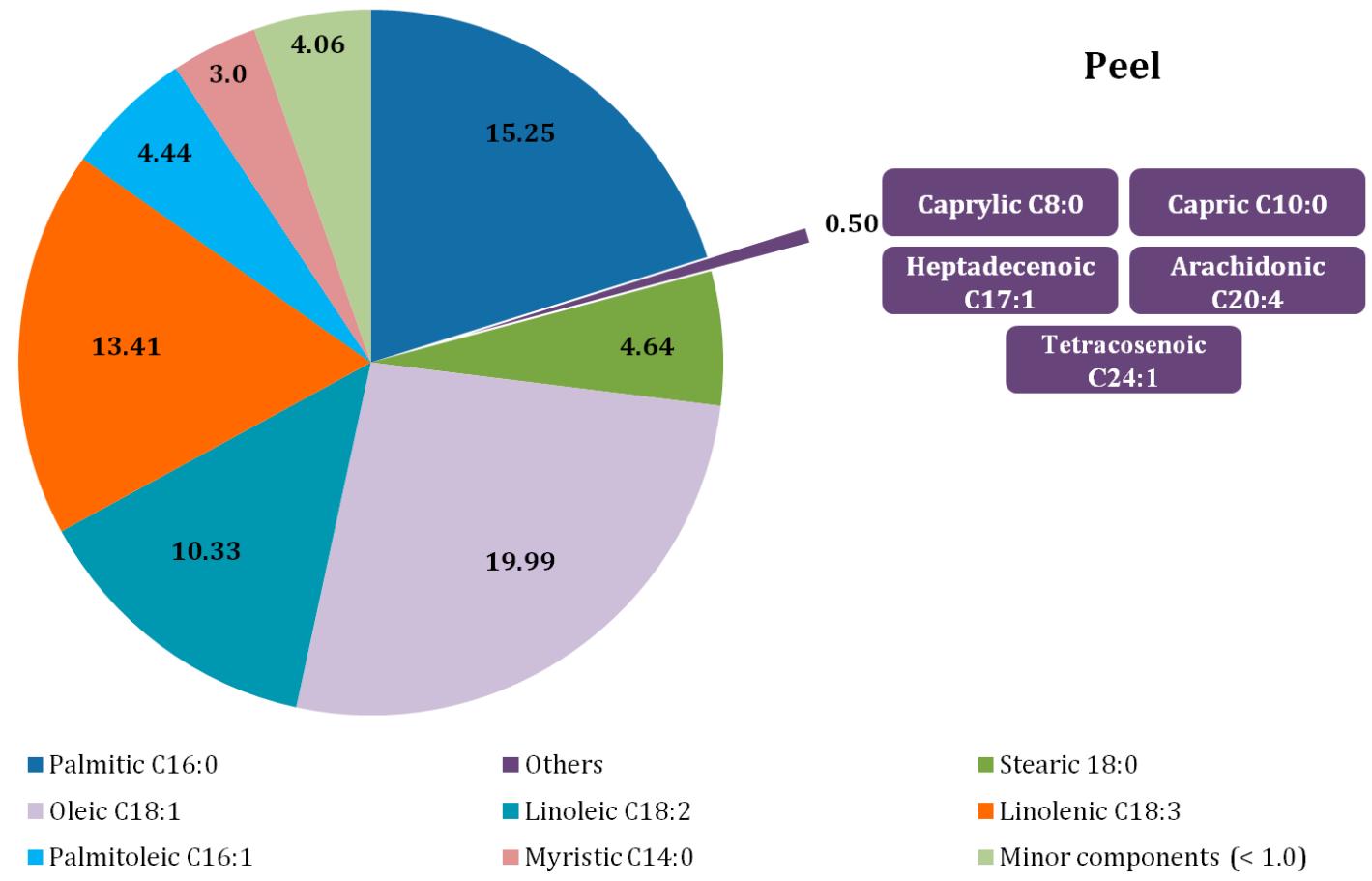

Figure 6 Fatty acid composition from peel of Asimina triloba (L.) Dunal (g/100 g oil)

Minor components (<1.0): Lauric C12:0 (0.39); Heptadecanoic C17:0 (0.24); Arachidic C20:0 (0.34); Eicosenoic C20:1 (0.30); Behenic C22:0 (0.98); Erucic C22:1 (0.13); Docosadienoic C22:2 (0.78); Lignoceric C24:0 (0.90) are in the right column, their total amount is $4.06 \mathrm{~g} / 100 \mathrm{~g}$ oil

As reported by Nam et al. (2018a) the contents of oleic and linoleic acids contained in the seeds were 5905.11 and $8045.56 \mathrm{mg} \%$, respectively, which was more than 120 times and 820 times the oleic and linoleic acids contained in the fruit, respectively.

Oleic acid and palmitic acid in pulp accounted for 28.66 and $24.67 \%$ of total fatty acids, followed by linolenic acid and linoleic acid, accounting for 12.54 and $7.89 \%$ of total fatty acids, respectively (Figure 5). Unsaturated fatty acids were also predominant in pulp, which accounted for $60.88 \%$ of total fatty acid while saturated fatty acids accounted for $39.12 \%$.

In peel, oleic acid, palmitic acid, linolenic acid, and linoleic acid accounted for 26.23, 20.01, 17.59, and $13.55 \%$ of total fatty acids, respectively (Figure 6). Stearic acid and palmitoleic acid were the minor fatty acids in the peel, accounting for 6.09 and $5.83 \%$ of the total fatty acids, respectively. Unsaturated fatty acids were also predominant in the peel, which accounted for $65.70 \%$ of total fatty acid while saturated fatty acids accounted for $34.30 \%$.

Oleic acid was present in the largest amount in the seeds, pulp, and peel. Oleic acid belongs to the omega-9 fatty acids. Omega-9 fatty acids (MUFAs) have one double bond per one molecule of a fatty acid. Oleic acid (18:1 $\mathrm{n}-9$ ), as the major MUFAs, is the main characteristic of the Mediterranean Style Diet, which is high in olive oil (Rustan and Drevon, 2005). The monounsaturated fatty acids (MUFAs) at normal amounts in the diet do not affect blood cholesterol levels (Hegsted et al., 1993). When polyunsaturated fatty acids in the diet are replaced by monounsaturated fatty acids, such as oleic acid, they do not increase blood cholesterol levels (cholesterolemia). However, increased MUFAs content in the diet lower than LDL- and total cholesterol and increases HDL-cholesterol (Mattson and Grundy, 1985), and thus MUFAs reduce the risk of cardiovascular disease.

The palmitic acid, stearic acid, and myristic acid belong to the saturated fatty acids (SFAs). SFAs increase and are the primary determinants of serum cholesterol. The polyunsaturated fatty acids (PUFAs) actively lower serum cholesterol (Hegsted et al., 1993). Dietary omega-3 polyunsaturated fatty acids ( $\omega-3$ PUFAs), including alpha-linolenic acid, docosapentaenoic acid, and eicosapentaenoic acid, are most studied. The anti-inflammatory and hypotriglyceridemic effects of these fatty acids are well known, whereas pro-inflammatory properties have been recognized in their dietary counterparts, the $\omega-6$ PUFAs (D'Angelo et al., 2020).

In order to comply with plant food safety requirements, the concentration of heavy metals in plants must be 
evaluated. Toxic elements including mercury, lead, and cadmium can be present in trace amounts. Major mineral elements such as iron, copper, zinc, and manganese should not exceed critical thresholds, as excessive concentrations are also toxic (Lekouch et al., 2001).

The average contents of the elements in the different parts of A. triloba are shown in Table 2. Macroelement and trace element concentrations in the leaf samples revealing the following trend: $\mathrm{Ca}>\mathrm{P}>\mathrm{Mg}>\mathrm{K}>\mathrm{S}>$ $\mathrm{Fe}>\mathrm{Zn}>\mathrm{Al}>\mathrm{Mn}>\mathrm{Cu}>\mathrm{Na}>\mathrm{Se}>\mathrm{Cr}>\mathrm{Ni}>\mathrm{Pb}>\mathrm{As}>$ $\mathrm{Hg}>\mathrm{Cd}$. These elements were also detected in seeds samples according to the following order: $\mathrm{K}>\mathrm{P}>\mathrm{Ca}$ $>\mathrm{S}>\mathrm{Mg}>\mathrm{Fe}>\mathrm{Zn}>\mathrm{Cu}>\mathrm{Na}>\mathrm{Mn}>\mathrm{Al}>\mathrm{Ni}>\mathrm{Se}>\mathrm{As}$ $>\mathrm{Cr}>\mathrm{Pb}>\mathrm{Cd}>\mathrm{Hg}$. In the pulp samples, the following concentrations were observed: $\mathrm{K}>\mathrm{P}>\mathrm{S}>\mathrm{Ca}>\mathrm{Mg}>\mathrm{Fe}$ $>\mathrm{Na}, \mathrm{Cu}>\mathrm{Al}>\mathrm{Zn}>\mathrm{Mn}>\mathrm{As}>\mathrm{Cr}, \mathrm{Se}, \mathrm{Ni}>\mathrm{Pb}>\mathrm{Cd}>\mathrm{Hg}$. In the peel samples, the following result was obtained: $\mathrm{K}>\mathrm{Ca}>\mathrm{P}>\mathrm{S}>\mathrm{Mg}>\mathrm{Fe}>\mathrm{Na}>\mathrm{Cu}>\mathrm{Al}>\mathrm{Zn}>\mathrm{As}>\mathrm{Cr}$, Se, $\mathrm{Ni}>\mathrm{Mn}>\mathrm{Pb}>\mathrm{Cd}>\mathrm{Hg}$.

For all of these elements, the required amount of the individual's daily intake ( $\mathrm{mg} /$ day) has been determined (Anke et al., 2002). The average concentrations of $\mathrm{Hg}$, As, and $\mathrm{Pb}$ analyzed in $A$. triloba were below the maximum allowable levels.

Table 2 shows that mineral elements are higher in the peel than in the other parts of $A$. triloba. K was the most abundant essential trace mineral element in different parts. There is more of this element in the peel $(15487 \mathrm{tmg} / \mathrm{kg})$ and pulp $(12198.0 \mathrm{mg} / \mathrm{kg})$ than in the seeds $(3888.0 \mathrm{mg} / \mathrm{kg})$. In the seeds, $\mathrm{P}, \mathrm{Ca}$ and $\mathrm{S}$ were higher than in pulp and peel. Seeds and pulp contribute moderate trace elements because of their high water content. Nam et al. (2018a) report that seeds (289.17 $\mathrm{mg} \%$ fresh weight) have more potassium content than fruits (239.36 mg\% fresh weight).

The many reports proposed that the chemical composition content may differ according to several factors such as growing season, cultivars, and climatic conditions (Rohloff et al., 2005; Jang et al., 2011; Nwofia et al., 2012). Therefore, the present study suggests that the chemical composition content of Asimina triloba can depend on their different parts, as well as these other factors.

Our conclusion provides additional information to elucidate the medical functions and nutritional properties of $A$. triloba. The fruits of A. triloba can also be recommended for use as a potential functional food, nutraceutical, or dietary food supplement in processed form.
Table 2 Mineral composition of different parts of Asimina triloba (L.) Dunal (mg/kg)

\begin{tabular}{|l||c|c|c|}
\hline Minerals & Seed $\left(\overline{\mathbf{x}} \pm \mathbf{S}_{\mathbf{x}}\right)$ & Pulp $\left(\overline{\mathbf{x}} \pm \mathbf{S}_{\mathbf{x}}\right)$ & Peel $\left(\overline{\mathbf{x}} \pm \mathbf{S}_{\mathbf{x}}\right)$ \\
\hline \hline $\mathbf{P}$ & $1937.0 \pm 122$ & $1046.0 \pm 75$ & $831.0 \pm 48$ \\
\hline $\mathbf{K}$ & $3888.0 \pm 215$ & $12198.0 \pm 334$ & $15487.0 \pm 361$ \\
\hline $\mathbf{C a}$ & $1368.0 \pm 96$ & $450.0 \pm 28$ & $837.0 \pm 31$ \\
\hline $\mathbf{S}$ & $1322.0 \pm 99$ & $499.0 \pm 31$ & $646.0 \pm 45$ \\
\hline Fe & $26.0 \pm 1.02$ & $25.0 \pm 1.12$ & $31.0 \pm 1.09$ \\
\hline $\mathbf{M n}$ & $7.1 \pm 0.5$ & $1.1 \pm 0.02$ & $1.5 \pm 0.01$ \\
\hline $\mathbf{M g}$ & $1021.0 \pm 65$ & $396.0 \pm 35$ & $573.0 \pm 47$ \\
\hline $\mathbf{N a}$ & $8.0 \pm 0.7$ & $5.0 \pm 0.2$ & $11.0 \pm 0.4$ \\
\hline $\mathbf{A l}$ & $1.1 \pm 0.01$ & $4.4 \pm 0.2$ & $3.7 \pm 0.2$ \\
\hline $\mathbf{C r}$ & $<0.2$ & $<0.2$ & $<0.2$ \\
\hline $\mathbf{C u}$ & $14.0 \pm 0.5$ & $5.0 \pm 0.3$ & $4.0 \pm 0.2$ \\
\hline $\mathbf{Z n}$ & $17.0 \pm 0.4$ & $3.0 \pm 0.1$ & $3.0 \pm 0.2$ \\
\hline Se & $0.25 \pm 0.05$ & $<0.2$ & $<0.2$ \\
\hline As & $<0.3$ & $<0.3$ & $<0.3$ \\
\hline $\mathbf{C d}$ & $0.050 \pm 0.002$ & $<0.01$ & $<0.01$ \\
\hline $\mathbf{N i}$ & $0.74 \pm 0.08$ & $<0.2$ & $<0.2$ \\
\hline $\mathbf{H g}$ & $0.009 \pm 0.0001$ & $0.007 \pm 0.0002$ & $0.006 \pm 0.0001$ \\
\hline $\mathbf{P b}$ & $<0.1$ & $<0.1$ & $<0.1$ \\
\hline
\end{tabular}

Note: $\overline{\mathrm{x}}$ - arithmetic mean; $\mathrm{S}_{\mathrm{x}}$ - standard error of the mean

\section{Conclusion}

Diverse amino acids, fatty acids, and mineral elements that are essential to human health were in Asimina triloba. The glutamic acid, oleic acid, linoleic acid, palmitic acid, K, P, Ca, and S were found in relatively high levels. High potassium content was found in all the plant parts of $A$. triloba. Considering these results, A. triloba fruits and seeds can contribute to the coverage of nutritional recommendations in human nutrition and some nutritional requirements in the human diet.

\section{Acknowledgments}

This work was supported by the Bilateral Scholarship of the Ministry of Education, Science, Research and Sport, SAIA, and Visegrad Fund (Slovak Republic). Experimental activities were realized in the laboratories of the Centre of Excellence for the Conservation and Use of Agrobiodiversity at the Faculty of Agrobiology and Food Resources, Slovak Agricultural University in Nitra.

\section{References}

ABEDI, E., SAHARI, M.A. 2014. Long-chain polyunsaturated fatty acid sources and evaluation of their nutritional and functional properties. In Food Science Nutrition, vol. 2(5), p. 443e63. 
ALALI, F.Q., LIU, X.X., MCLAUGHLIN, J.L. 1999. Annonaceous acetogenins: recent progress. In Journal of Natural Products, vol. 62(3), p. 504-540. http://dx.doi.org/10.1021/np980406d

ANDERSON, J.W.1986. Dietary fiber in nutrition management of diabetes. In: Vahouny, G.V., Kritchevsky, D. (eds.), Dietary Fiber: Basic and Clinical Aspects, 343-360. New York, USA: Plenum Press.

ANKE, M., GLEI, M., DORN, W., MULLER, R., VORMANN, J., MULLER, M., JAHRITZ, M., SEIFERT, M., HOLZINGER, S., DROBNER, S., ROHRIG, B., ROTHER, C., ANGELOW, L., LATUNDE-DADA, G.O. 2002. Trace element intake and balance in adults in Central Europe. In Trace Elements in Man and Animals, vol. 10, p. 209-214. https://doi.org/10.1007/0-306-47466-2 56

ARORA, A., CHOUDHARY, D., AGARWAL, G., SINGH, V.P. 2008. Compositional variation in $\beta$-carotene content, carbohydrate and antioxidant enzymes in selected banana cultivars. In International Journal of Food Science and Technology, vol. 43(11), p. 1913-1921.

BATES, P.D., STYMNE, S., OHLROGGE, J. 2013. Biochemical pathway in seed oil synthesis. In Current Opinion in Plant Biology, vol. 16, p. 358-364. https://dx.doi.org/10.1016/i.pbi.2013.02.015

BRANNAN, R.G.,PETERS, T., TALCOTT,S.T.2014.Phytochemical Analysis of ten varieties of pawpaw (Asimina triloba (L.) Dunal) fruit pulp. In Food Chemistry, vol. 168, p. 656-661. http://dx.doi.org/10.1016/j.foodchem.2014.07.018

BRANNAN, R.G., SALABAK, D.E., HOLBEN, D.H. 2012. Sensory analysis of pawpaw (Asimina triloba) pulp puree: Consumer appraisal and descriptive lexicon. In Journal of Food Research, vol. 1(1), p. 179-192. http://dx.doi.org/10.5539/jfr.v1n1p179

BRINDZA, J., GRYGORIEVA, O., KLYMENKO, S., VERGUN, O., MAREČEK, J., IVANIŠOVÁ, E. 2019. Variation of fruits morphometric parameters and bioactive compounds of Asimina triloba (L.) Dunal germplasm collection. In Potravinarstvo Slovak Journal Food Sciences, vol. 13(1), p. 1-7. https://doi.org/10.5219/1019

BRINDZA, J., TOTH, D., BRINDZA, P., GRYGORIEVA, O., SAJBIDOR, J., KUCELOVA, L. 2016. Forgotten and Less Utilised Plant Species as Functional Food Resources. In: Kristbergsson K., Ötles S. (eds) Functional Properties of Traditional Foods. Integrating Food Science and Engineering Knowledge Into the Food Chain, vol. 12. Springer, Boston, MA. https://doi.org/10.1007/978-1-4899-7662-8_15

BRINDZA, J., TOTH, D., HOLECYOVA, J., ČERVEŇAKOVA, J., BRINDZA, P., DITETOVA, K. 2006. Non-traditional fruit species: potential resources of functional food. In Scandinavian Journal of Food and Nutrition, vol. 50(1), p. 37-38.

BUDHALAKOTI, N. 2018. Evaluation of $\beta$-carotene content and antioxidant activity of banana peels and banana peel extracted insoluble dietary fibres. In International Journal of Agriculture, Environment and Biotechnology, vol. 11(5), p. 781-789.
CUENDET, M., OTEHAM, C.P., MOON, R.C., KELLER, W.J., PEADEN,P.A.,PEZZUTO,J.M.2008.DietaryAdministration of Asimina triloba (Paw Paw) extract increases tumor latency in n.-methyl-n.-nitrosourea-treated rats. In Pharmaceutical Biology, vol. 46(1-2), p. 3-7. https://doi.org/10.1080/13880200701729497

D'ANGELO, S., MOTTI, M.L., MECCARIELLO, R. 2020. $\omega-3$ and $\omega-6$ Polyunsaturated Fatty Acids, Obesity and Cancer. In Nutrients, vol. 12(9), p. 2751. https://doi.org/10.3390/nu12092751

DE CATERINA, R., LIAO, J.K., LIBBY, P. 2000. Fatty acid modulation of endothelial activation. In American Journal of Clinical Nutrition, vol. 71(1), p. 213Se23S.

DELGADO-PELAYO, R., GALLARDO-GUERRERO, L., HORNEROMÉNDEZ, D. 2014. Chlorophyll and carotenoid pigments in the peel and flesh of commercial apple fruit varieties. In Food Research International, vol. 65, p. 272-281. https://doi:10.1016/j.foodres.2014.03.025

DHANDAPANI, R., SINGH, V.P., BHATTACHARYA, R.C., RAJENDRAN, A. 2017. Differential accumulation of $\beta$-carotene and tissue specific expression of phytoene synthase (MaPsy) gene in banana (Musa sp) cultivars. In Journal of Food Science and Technology, vol. 54 (13), p. 4416-4426. https://doi.org/10.1007/s13197-017-2918-8

DIVIS, P., PORIZKA, J., VESPALCOVA, M., MATEJICEK, A., KAPLAN, J. 2015. Elemental composition of fruits from different black elder (Sambucus nigra L.) cultivars grown in the Czech Republic. In Journal of Elementology, vol. 20(3), p. 549-557. https://doi.org/10.5601/jelem.2015.20.1.758

FARAG, M.A. 2009. Chemical composition and biological activities of Asimina triloba leaf essential oil. In Pharmaceutical Biology, vol. 47(10), p. 982-986. https://doi.org/10.1080/13880200902967995

GALLI, F., ARCHBOLD, D.D., POMPER, K.W. 2007. Pawpaw: An old fruit for new needs. In Acta Horticulturae, vol. 744, p. 461-466. https://doi.org/10.17660/ActaHortic.2007.744.56

GHOSH, S., CHATTERJEE, J.K., CHALKROBORTY, B., KUNDU, P. 2019. Estimation of beta carotene from fruit peel wastes by high performance thin layer chromatography. In Journal of Pharmacognosy and Phytochemistry, vol. 8(1), p. 2598-2600.

GOODRICH, K.R., ZJHRA, M.L., LEY, C.A., RAGUSO, R.A. 2006. When flowers smell fermented: the chemistry and ontogeny of yeasty floral scent in pawpaw (Asimina triloba: Annonaceae). In International Journal Plant Sciences, vol. 167(1), p. 33-46. https://doi.org/10.1086/498351

GRYGORIEVA, O., KLYMENKO, S., VERGUN, O., MŇAHONČÁKOVÁ, E., BRINDZA, J., TERENTJEVA, M., IVANIŠOVÁ,E.2020a.Evaluation of theantioxidantactivity and phenolic content of Chinese quince (Pseudocydonia sinensis Schneid.) fruit. In Acta Scientiarum Polonorum. Technologia Alimentaria, vol. 19, p. 25-36. http://dx.doi.org/10.17306/J.AFS.2020.0738 
GRYGORIEVA, O., KUCHARSKA, A.Z., PIÓRECKI, N., KLYMENKO, S., VERGUN, O., BRINDZA, J. 2018. Antioxidant activities and phenolic compounds in fruits of various genotypes of American persimmon (Diospyros virginiana L.). In Acta Scientiarum Polonorum Technologia Alimentaria, vol. 17(2), p. 117-124. http://doi.org/10.17306/J.AFS.0544

GRYGORIEVA, O., VERGUN, O., KLYMENKO, S., ZHURBA, M., HORČINOVÁ SEDLÁČKOVÁ, V., IVANIŠOVÁ, E., BRINDZA, J. 2020b. Estimation of phenolic compounds content and antioxidant activity of leaves extracts of some selected non-traditional plants. In Potravinarstvo Slovak Journal of Food Sciences, vol. 14, p. 501-509. https://doi.org/10.5219/1314

GU, Z.-M., ZHOU, D., LEWIS, N.J., WU, J., JOHNSON, H.A., MCLAUGHLIN, J.L., GORDON, J. 1999. Quantitative evaluation of Annonaceous acetogenins in monthly samples of paw paw (Asimina triloba) twigs by liquid chromatography/electrospray ionization/ tandem mass spectrometry. In Phytochemical Analysis, vol. 10(1), p. 32-38. https://doi.org/10.1002/ (SICI)1099-1565(199901/02)10:13.0.CO;2-D

HARRIS, G.G., BRANNAN, R.G. 2009. A preliminary evaluation of antioxidant compounds, reducing potential, and radical scavenging of pawpaw (Asimina triloba) fruit pulp from different stages of ripeness. In LwtFood Science and Technology, vol. 42(1), p. 275-279. http://dx.doi.org/10.1016/j.lwt.2008.05.006

HEGSTED, D.M., AUSMAN, L.M., JOHNSON, J.A., DALLAL, G.E. 1993. Dietary fat and serum lipids: an evaluation of the experimental data. In American Journal of Clinical Nutrition, vol. 57(6), p. 875-883. https://doi/10.1093/ajcn/57.6.875

HORČINOVÁ SEDLÁČKOVÁ, V., GRYGORIEVA, O., FATRCOVÁŠRAMKOVÁ, K., VERGUN, O., VINOGRADOVA, Y., IVANIŠOVÁ, E., BRINDZA, J. 2018. The morphological and antioxidant characteristics of inflorescences within wild-growing genotypes of elderberry (Sambucus nigra L.). In Potravinarstvo Slovak Journal of Food Sciences, vol. 12(1), p. 444-453. https://doi.org/10.5219/919

HUI, Y.H., RUPPRECHT, J.K., LIU, Y.M., ANDERSON, J.E., SMITH, D.L., CHANG, C.J., MCLAUGHLIN, J.L. 1989. Bullatacin and bullatacinone: two highly potent bioactive acetogenins from Annona bullata. In Journal Natural Products, vol. 52(3), p. 463-477. http://dx.doi.org/10.1021/np50063a002

CHITTURI, S., TALATAM, V.G., VUPPU, S. 2013. Studies on protein content, protease activity, antioxidants potential, melanin composition, glucosinolate and pectin constitution with brief statistical analysis in some medicinally significant fruit peels. In Der Pharmacia Lettre, vol. 5(1), p. 13-23.

IVANIŠOVÁ, E., GRYGORIEVA, O., ABRAHAMOVÁ, V., SCHUBERTOVA, Z., TERENTJEVA, M., BRINDZA, J. 2017. Characterization of morphological parameters and biological activity of jujube fruit (Ziziphus jujuba Mill.). In Journal of Berry Research, vol. 7(4), p. 249-260. https://doi.org/10.3233/JBR-170162
JANG, H.L., HONG, J.Y., KIM, N.J., KIM, M.H., SHIN, S.R., YOON, K.Y. 2011. Comparison of nutrient components and physicochemical properties of general and colored potato. In Korean Journal of Horticultural Science and Technology, vol. 29, p. 144-150.

JONES, L., LAYNE, D.R., KWANTES, M.G. 1995. Pawpaw (Asimina triloba) seedling growth and development: Influence of incident light intensity and fertilization regime. In HortScience, vol. 30(3), p. 437.

KABELOVA, J., DVORAKOVA, M., CIZKOVA, H., DOSTALEK, P., MELZOCH, K. 2008. Determination of free amino acids in beers: a comparison of Czech and foreign brands. In Journal of Food Composition and Analysis, vol. 21, p. 726-741.

KAUR, P., GHOSHAL, G., JAIN, A. 2018. Bio-utilization of Fruits and Vegetables Waste to Produce $\beta$-Carotene in SolidState Fermentation; Characterization and Antioxidant Activity. In Process Biochemistry, vol. 76, p. 155-164. https://doi:10.1016/j.procbio.2018.10.007

KLYMENKO, S., GRYGORIEVA, O., BRINDZA, J. 2017. Less known species of fruit crops. Slovak University of Agriculture in Nitra. http://dx.doi.org/10.15414/2017.fe-9788055217659

KLYMENKO, S., KUCHARSKA, A.Z., SOKÓŁ-ŁĘTOWSKA, A., PIÓRECKI, N. 2019. Antioxidant activities and phenolic compounds in fruits of cultivars of cornelian cherry (Cornus mas L.). In Agrobiodiversity for Improving Nutrition, Health and Life Quality, vol. 3, p. 484-499. https://doi.org/10.15414/ agrobiodiversity.2019.2585-8246.484-4

KO, Y., WU, T., WU, Y., CHANG, F., GUH, J., CHUANG, L. 2011. Annonacin induces cell cycle-dependent growth arrest and apoptosis in estrogen receptor- $\alpha$-related pathways in MCF-7 cells. In Journal Ethnopharmacology, vol. 137(3), p. 1283-1290. https://doi.org/10.1016/j.jep.2011.07.056

KOBAYASHI, H., WANG, C., POMPER, K.W. 2008. Phenolic content and antioxidant capacity of pawpaw fruit (Asimina triloba L.) at different ripening stages. In HortScience, vol. 43, p. 268-270.

KURAHASHI, N., INOUE, M., IWASAKI, M., TANAKA, Y., MIZOKAMI, M., TSUGANE, S. 2009. Vegetable, fruit and antioxidant nutrient consumption and subsequent risk of hepatocellular carcinoma: a prospective cohort study Japan. In British Journal of Cancer, vol. 100, p. 181-184.

LAYNE, D.R. 1996. The pawpaw (Asimina triloba (L.) Dunal): a new fruit crop for Kentucky and the United States. In HortScience, vol. 31(5), p. 775-784.

LEKOUCH, N., SEDKI, A., NEJMEDDINE, A., GAMON, S. 2001. Lead and traditional Moroccan pharmacopoeia. In Science of the Total Environment, vol. 280, p. 39-43. https://doi.org/10.1016/s0048-9697(01)00801-4

LIU,J.,HUA,W.,YANG,H.,GUO,T.,SUN,X.,WANG,X.,LIU,G.,WANG, H. 2014. Effect of specific organs on seed oil accumulation in Brassica napus L. In Plant Science, vol. 227, p. 60-68. https://dx.doi.org/10.1016/j.plantsci.2014.06.017

MATTSON, F.H., GRUNDY, S.M. 1985. Comparison of effects of dietary saturated, monounsaturated, and 
polyunsaturated fatty acids on plasma lipids and lipoproteins in man. In Journal of Lipid Research, vol. 26(2), p. 194-202.

McGAW, L.J., JÄGER, A.K., VAN STADEN, J. 2002. Isolation of antibacterial fatty acids from Schotia brachypetala. In Fitoterapia, vol. 73(5), p. 431e3.

MONKA, A., GRYGORIEVA, O., CHLEBO, P., BRINDZA, J. 2014. Morphological and antioxidant characteristics of quince (Cydonia oblonga Mill.) and Chinese quince fruit (Pseudocydonia sinensis Schneid.). In Potravinarstvo, vol. 8, p. 333-340. https://doi.org/10.5219/415

NAM,J.S.,JANG,H.L., RHEE,Y.H.2018a.Nutritionalcompositions in roots, twigs, leaves, fruit pulp, and seeds from pawpaw (Asimina triloba [L.] Dunal) grown in Korea. In Journal of Applied Botany and Food Quality, vol. 91, p. 47-55. https://doi.org/10.5073/JABFQ.2018.091.007

NAM, J.S., PARK, S.Y., LEE, H.J., LEE, S.O., JANG, H.L., RHEE, Y.H. 2018b. Correlation between acetogenin content and antiproliferative activity of pawpaw (Asimina triloba [L.] Dunal) fruit pulp grown in Korea. In Journal Food Science, vol. 83(5), p. 1430-1435. https://doi.org/10.1111/1750-3841.14144

NWOFIA, G.E., OJIMELUKWE, P., EJI, C. 2012. Chemical composition of leaves, fruit pulp and seeds in some Carica papaya (L) morphotypes. In International Journal of Medicinal and Aromatic Plants, vol. 2, p. 200-206.

PANDE, G., AKOH, C.C. 2010. Organic acids, antioxidant capacity, phenolic content and lipid characterisation of Georgia-grown underutilized fruit crops. In Food Chemistry, vol. 120(2), p. 1067-1075.

https://doi.org/10.1016/j.foodchem.2009.11.054

POMPER, K.W., LAYNE, D.R. 2005. The North American pawpaw: botany and horticulture. In Horticultural Reviews, vol. 31, p. 351-384.

https://doi.org/10.1002/9780470650882.ch7

RANGANATH, K.G., SHIVASHANKARA, K.S., ROY, T.K., DINESH, M.R., GEETHA, G.A., PAVITHRA, K.C., RAVISHANKAR, K.V. 2018. Profiling of anthocyanins and carotenoids in fruit peel of different colored mango cultivars. In Journal of Food Science and Technology, vol. 55(11), p. 4566-4577. https://doi.org/10.1007/s13197-018-3392-7

RATNAYAKE, S., RUPPRECHT, J.K., POTTER, W.M., MCLAUGHLIN, J.L. 1992. Evaluation of various parts of the paw paw tree, Asimina triloba (Annonaceae), as commercial sources of the pesticidal annonaceous acetogenins. In Journal Economic Entomology, vol. 85(6), p. 2353-2356.

https://doi.org/10.1093/jee/85.6.2353

ROHLOFF, J., ULEBERG, E., NES, A., KROGSTAD, T., NESTBY, R., MAR-TINUSSEN, I. 2005. Nutritional composition of bilberries (Vaccinium myrtillus L.) from forest fields in Norway - Effects of geographic origin, climate, fertilization and soil properties. In Journal of Applied Botany and Food Quality, vol. 88, p. 274-287. https://doi.org/10.5073/JABFQ.2015.088.040

RUPPRECHT, J.K., CHANG, C.-J., CASSADY, J.M., MCLAUGLIN, J.L. 1986. Asimicin, a new cytotoxic and pesticidal acetogenin from the pawpaw, Asimina triloba (Annonaceae). In Heterocycles, vol. 24(5), p. 1197-1201. https://doi.org/10.3987/R-1986-05-1197

RUSTAN, A.C, DREVON, C.A. 2005. Fatty Acids: Structures and Properties. London: Encyclopedia of Life Sciences, Nature Publishing.

SEDLACEK, J.D., FRILEY, K.L., LOWE, J.D., POMPER, K.W. 2010. Potential of ripe pawpaw fruit extract as an insecticide and feeding deterrent for striped cucumber beetle (Coleoptera: Chrysomelidae) on Squash. In Journal of Entomological Science, vol. 45(4), p. 378-384. https://doi.org/10.18474/0749-8004-45.4.378

SEIDEL, V., TAYLOR, P.W. 2004. In vitro activity of extracts and constituents of Pelargonium against rapidly growing mycobacteria. In International Journal Antimicrobial Agents, vol. 23(6), p. 613e9.

SICA, V.P., EL-ELIMATA, T., OBERLIES, N.H. 2016. In situ analysis of Asimina triloba (paw paw) plant tissues for acetogenins via the droplet-liquid microjunctionsurface sampling probe coupled to UHPLC-PDAHRMS/MS. In Analytical methods : advancing methods and applications, vol. 8(32), p. 6143-6149. https://doi.org/10.1039/C6AY01583B

SINESIO, F., COMENDADOR, F.J., PEPARAIO, M., MONETA, E. 2009. Taste perception of umami rich dishes in Italian culinary tradition. In Journal of Sensory Studies, vol. 24, p. 554-580.

TEMPLETON, S.B., MARLETTE, M., POMPER, K.W., JONES, S.C. 2003. Favorable taste ratings for several pawpaw products. In Horticultural Technology, vol. 13, p. 445-448.

VINOGRADOVA, Y., VERGUN, O., GRYGORIEVA, O., IVANIŠOVÁ, E., BRINDZA, J. 2020. Comparative analysis of antioxidant activity and phenolic compounds in the fruits of Aronia spp. In Potravinarstvo Slovak Journal of Food Sciences, vol. 14, p. 393-401. https://doi.org/10.5219/1360

WOO, M.H., ZENG, L., YE, Q., GU, Z., ZHAO, G., MCLAUGHLIN, J.L. 1995. 16, 19-cis-Murisolin and murisolin A, two novel bioactive mono-tetrahydrofuran annonaceous acetogenins from Asimina triloba seeds. In Bioorganic Medicinal Chemistry Letters, vol. 5(11), p. 1135-1140. https://doi.org/10.1016/0960-894X(95)00182-S

ZHAO, G., HUI, Y., RUPPRECHT, J.K., MCLAUGHLIN, J.L., WOOD, K.V. 1992. Additional bioactive compounds and trilobacin, a novel highly cytotoxic acetogenin, from the bark of Asimina triloba. In Journal Natural Products, vol. 55(3), p. 347-356. https://doi.org/10.1021/np50081a011

ZHAO, G.X., MIESBAUER, L.R., SMITH, D.L., MCLAUGHLIN, J.L. 1994. Asimin, asiminacin, and asiminecin: Novel highly cytotoxic asimicin isomers from Asimina triloba. In JournalofMedicinalChemistry, vol.37(13), p. 1971-1976. https://doi.org/10.1021/jm00039a009

ZHAO, G.X., RIESER, M.J., HUI, Y.H., MIES BAUER, L.R., SMITH, D.L., MCLAUGHLIN, J.L. 1993. Biologicallyactive acetogenins from stem bark of Asimina triloba. In Phytochemistry, vol. 33(5), p. 1065-1073. https://doi.org/10.1016/0031-9422(93)85024-L 